Egyptian Journal of Archaeological and Restoration Studies "EJARS"

An International peer-reviewed journal published bi-annually

Original article

\title{
FRAGMENT OF BLOCK STATUE
}

\author{
Faheed, H. A. \\ Lecturer Department of Egyptology, Faculty of Arts, Sohag University, Egypt \\ Faheedahmed@yahoo.com
}

\begin{abstract}
The block statues appeared firstly at the very beginning of the 12th dynasty. They were made of rocky blocks with geometrical criteria. These statues personified the characters that they express. They were Sculpted Sitting on the ground, and his two legs standing vertically before him, and his arms resting straight on his knees. This type of statues was exceptionally preferred to other types of statues from the very beginning of the Middle kingdom till the Greco-Roman period. This traditional type of statues has been developed as a block statue. The sculptor began gradually to produce this type of statues of bodies and arms, legs and foot. Also the Sculptors began to form statues dressed in garments that caver the legs, some personalities have been Sculpted settling on a column that stands for the back. The block statues were in various forms and in one types clearly at the very beginning of the 18th.Dynasty, regardless of the reference to the details in all cases. Among these, block statues some types have appeared with its some of these block statues have appeared in small size of the gods or symbols for the gods sculpted in relief. These type statues continued to appear the end of the new kingdom.
\end{abstract}

Keywords: Block statue, Ahmes-Nefertary, Men-set, Hout-nesout, Amen-Re

\section{Introduction}

The statue ANX84 comes from a small annex in the Sheikh Labib Magazine, in the temple of Karnak, opened in 1998. Its provenance remains unknown. It is of the type called block statue [1] representing the owner squatting with his legs raised vertically in front of him and arms folded on the knees, the whole figure is hidden in along mantel. It is a statue form that appeared in the middle kingdom and continued in use throught the rest of the pharaonic period. These statues were set up in temples. The bore inscriptions that often addressed passersby and requested that the owner might partake of the offerings that came forth from the altars of the gods. Our statue has been severely damaged only the left side remains.

\section{Description:}

Fragment of block statue.

Limestone. High: $27 \mathrm{~cm}$; width: $10 \mathrm{~cm}$; length: $22,5 \mathrm{~cm}$.

On front of the statue: fig .1, pl. 1 


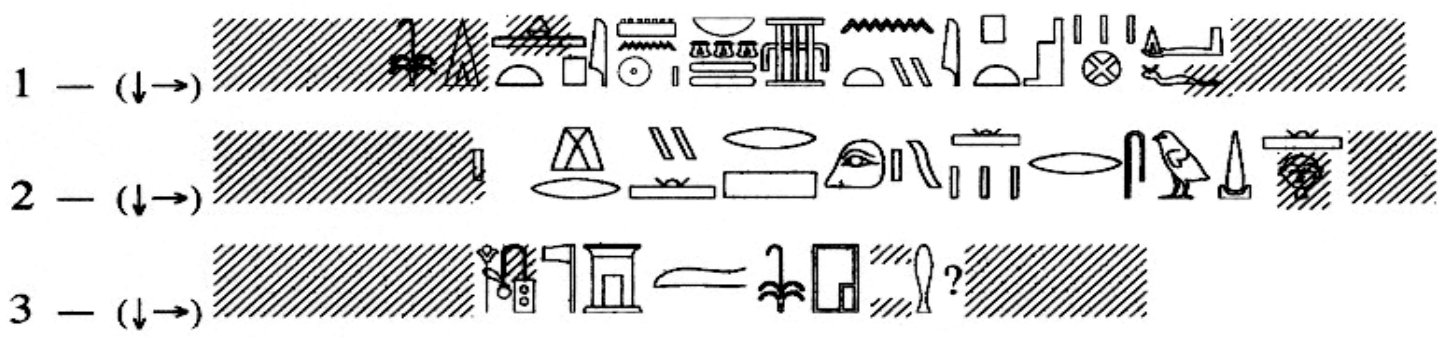

${ }^{[1]}[\ldots . . H]$ tp- [di-nswt] Imn- $R^{\complement}$ nb nswt t3wy, hnty Ipt-swt, di.f [...]

[2] [...] hry, ř̌w r swd 3 [hr (?)]

[3] [...] šs sh- ntr m Hwt-nswt...

[1] [An Of] fering, (which) [the king gives to] Amen-Re, Lord of the thrones of the Two Lands, so that he may give $[\ldots]^{[2]}$ under total joy, in order to take pleasure [in...][3] [...for] the scribe of the temple in Hout- nesout the Palace? [2]

Several officials bear titles connected with the domain of Hwt-nswt [3] which appears to have been located on the west bank at Thebes, (H. Gauthier, Dic. Geog.4, p.85-86, from statue CGC 42185);

-Ramsesnakht, high priest of Ra-Atum at Thebes, royal scribe and chief of the house in Hwt-nswt (CGC 42162);

-Amunmes, responsible for the offering in Hwt- nswt (CGC 42176);
-Rome-Roi, sem-priest in Hwt- nswt on the West of Thebes (CGC 42185);

-Ipuy, divine father of Amun in Hwtnswt (CGC 42187); none of them, nevertheless, is (scribe of the temple in $H w t-n s w t$ ), neither has any connection with the temple of Ahmes-Nefertary in mn-st (see under), hence the owner of the statue remains indefinite.

\section{-right side}

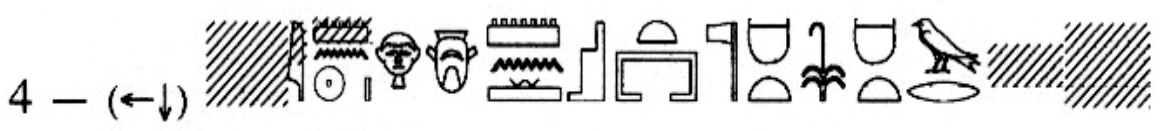

${ }^{[4]}[. .$.$] Imn-R { }^{e}$ hry-ib Mn-st, hmt ntr himt nswt wrt [...] [...prophet ? of ] Amun-Ra who dwells in Men-set, [4] ( and of )the god's wife, great king's wife , [ Ahmes - Nefertary ]

The cult of Amun in the mortuary temple of Ahmes-Nefertary must have reached certain importance as in some list of Theban deities, Amun of Mn-st comes at the head, followed by Ahmes-Nefertary of Mn-st, then comes the Amun of karnak, and then Amun of Deir alMedina (M. Gitton, L' epouae du dieu Ahmes-Nefertary, 1981, p. 76, quoting O. I. Chcago $\mathrm{n}^{\mathrm{o}} 16991$, A4.; cf. Wente, JNES 20,1961, p. 253 ).

Back pillar: fig .2, pl. 2

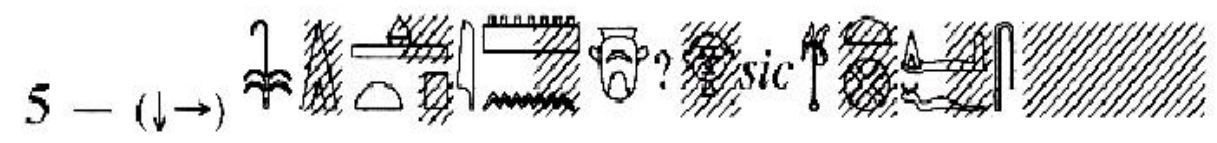

${ }^{5]} \mathrm{Htp}[\mathrm{di}]$ nswt Imn [hry] - ib w3st . di f. f $s[\mathrm{nb} . .$.$] \quad -$

[5j [ An of]fering, which the king [ gives to ] Amun, who dwells in Thebes, so that he may give health ( ? ) $[\ldots]$. 
For Imn hry - ib w3st, see L. A. Christophe, Les divinites de la Salle hypostyle, BdE 21, column n. 127 (4), \& 189 an column n . $134 \& 341$.

Shoulder: pl. 3

-[6] wsr - MAat - Ra [...]

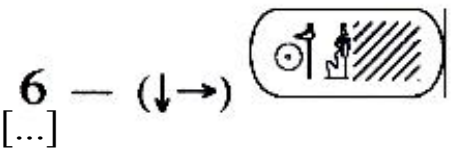

[6] Ouser - maat - Ra [...].

\section{Conclusion}

It is a new kind of statues appeared since the middle kingdom and continued after that in the following periods of Ancient Egypt. The sitting statues are rounded in squatting position. Sometimes wearing a cloak covering all his vaulted body, the aim is showing a high degree of a kneeling scared person before the gods. These statues are dedicated to gods' houses "temples" loving and aiming at intercession and acceptance. The history of this statue is due to the period of Ramesses, and perhaps texts only dated to the reign of Ramses IV.

\section{References}

[1] Lexikon der Agyptogie VI, 129192.,Bothmer,Bernard V., The Block Statue of Ankh-Khonsu in Boston and Cairo, MDAIK 37,p.75-85.,id, Block Statues of Dynasty XXV, BdE 106, p.61-68.,Wildung, Dietrich, Ein wurfelhocker des Generals"Nes-Month", MDAIK37,1981,p.503-507.

[2] For sH-nTr)see Spencer Patricia, The Egyptian temple :a lexicographical study , London, 1984., id, Studies in the lexicography of ancient Egyptian buildings and their parts, Boston, 1981., Konrad, Kirsten, Architektur und theologie: pharaonische templeterminologie, unter Berucksichtigung

Konigsideologischer Aspekte, KSG 5, 2006., Kuhlmann,Klaus-Peter, Bietak, Manfred, Serif-Style Architecture and the Design of the Archaic Egyptian Palace ( Konigs
Zelt ), UOAI 14, 1996., Janosi,peter, Gundlach, Rolf, Die Entwicklung und Deutung des totenopferraums in den Pyramidentempeln des AR, HAB 37,1994, p.143-163

[3] For@wt- nswt see Mostafa, Maha M.farid, Die Datierung der zweiten Benutzungsphase des Grabes TT257,SAK 20, 1993, p. 165 - 172 , id, Die Bezeichnug Hwt- Njswt, SAK 19 1992, p.239-247, Gestermann,Louise, Neue spuren des ptolemaischen Tempels am Kom al - ahmar bei Scharuna, MDAIK 48, 1992,p.1135.,Zaghloul, el-Hussein Omar M., An Agreement for Sale from the Reign of Ptolemy 1X Soter 11: in the museum of Mallawi (the Mallawi Papyri of Sharona 1) BIFAO 91, 1991,p.255-264.

[4] C. Leitz ( ed.) LGG III, 283a 


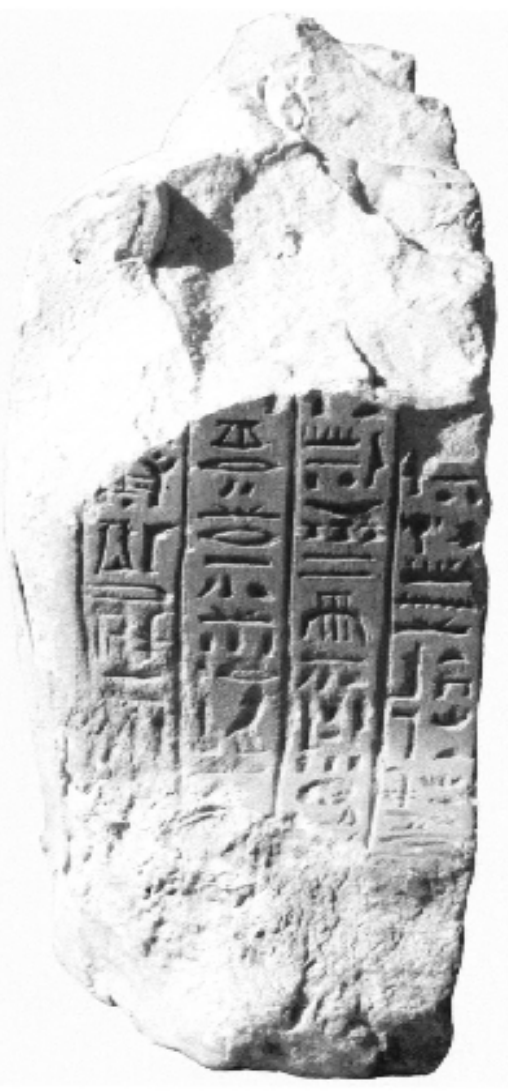

PI. 1

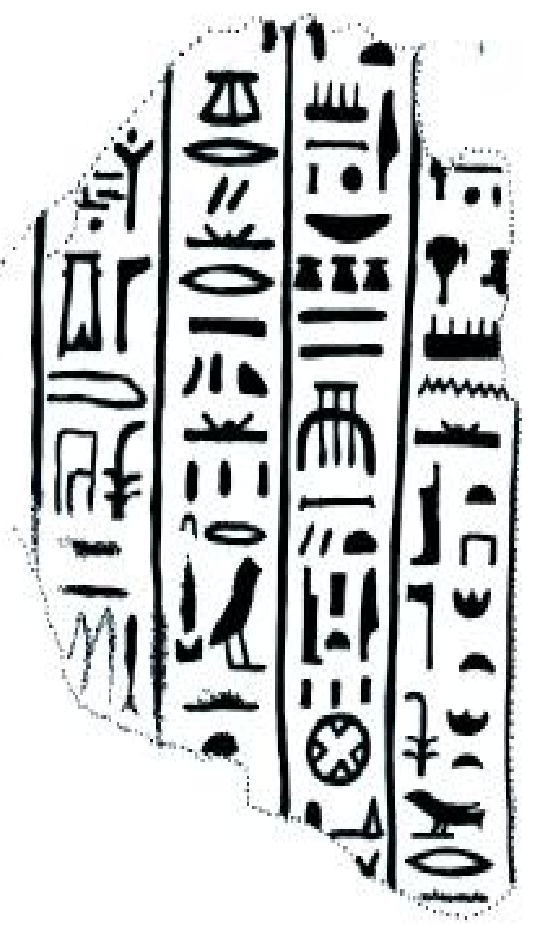

Fig . 1

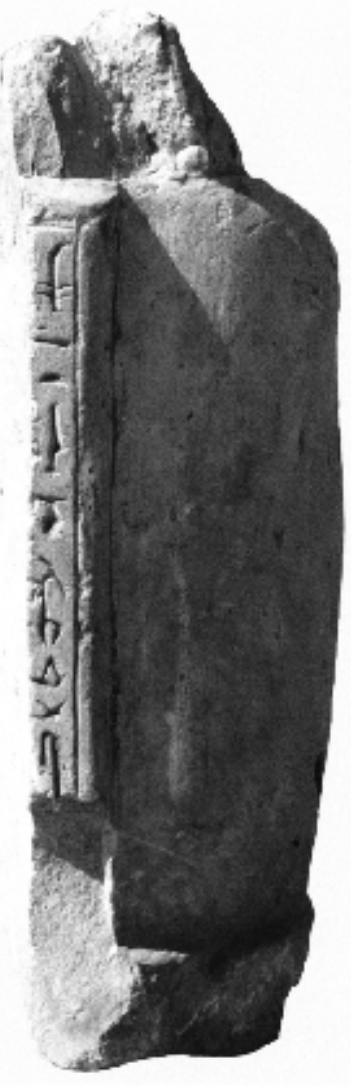

PI . 2

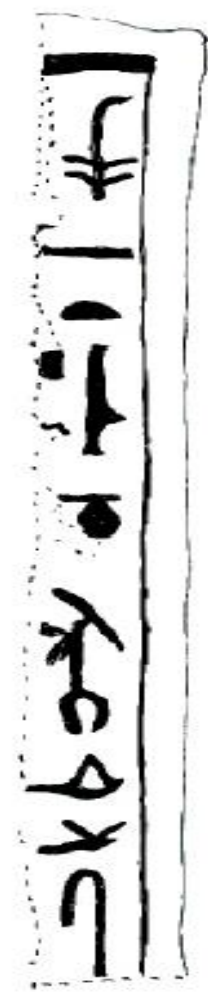

Fig . 2 